\title{
HUBUNGAN PENGETAHUAN DAN SIKAP IBU TENTANG ANTISIPASI CEDERA DENGAN PRAKTIK PENCEGAHAN CEDERA PADA ANAK USIA 1 - 3 TAHUN
}

\author{
Ratna Indriati, Endang Dwi Ningsih \\ STIKES Panti Kosala, Sukoharjo, Jawa Tengah, Indonesia
}

\begin{abstract}
Abstrak
Latar belakang : karakteristik anak usia toddler yang khas yaitu anak tidak bisa diam, bergerak terus serta kurangnya impuls kontrol berkontribusi pada insiden cedera yang tidak disengaja dalam usia toddler. Orang tua merupakan pihak yang bertanggung jawab terhadap kejadian cedera pada anak toddler. Praktik pencegahan cedera orang tua akan menurunkan kejadian cedera pada anak. Pengetahuan dan sikap merupakan faktor yang bisa mempengaruhi perilaku ibu dalam upaya pencegahan cedera pada anak.

Tujuan penelitian : untuk mengetahui hubungan pengetahuan dan sikap ibu dengan praktik pencegahan cedera pada anak usia $1-3$ tahun.

Subjek penelitian: adalah 40 ibu yang memiliki anak usia $1-3$ tahun di Dusun Daleman Desa Jetis.

Metode : penelitian berupa observasi analitik, desain korelasi dengan metode cross sectional. Pengambilan sampel secara sampling jenuh. Data yang diperoleh dianalisa menggunakan uji Chi Square dengan $\mathrm{p}: 0.05$.

Hasil Penelitian : menunjukkan responden dengan pengetahuan tinggi 29 ibu $(72,5 \%)$ pengetahuan sedang $11 \mathrm{ibu}(27,5 \%)$, sikap positif 36 ibu (90\%) sikap negatif 4 ibu (10\%). Praktik pencegahan optimal 31 ibu $(77,5 \%)$ kurang optimal 9 ibu (22,5\%). Hasil analisis hubungan pengetahuan ibu dengan praktik pencegahan cedera diperoleh $p=0,211$ $(p>0,05)$ yang berarti $\mathrm{Ha}$ ditolak dan hubungan sikap ibu dengan praktik pencegahan cedera diperoleh $p=0,008(p<0,05)$ yang berarti Ha diterima dengan $\mathrm{OR}=15,00$.

Kesimpulan : pengetahuan tidak memiliki hubungan dengan praktik pencegahan cedera dan sikap memiliki hubungan yang bermakna dengan praktik pencegahan cedera.
\end{abstract}

Kata kunci : pengetahuan, praktik pencegahan cedera, sikap

\section{THE RELATIONSHIP BETWEEN KNOWLEDGE AND ATTITUDES OF MOTHERS WITH INJURY PREVENTION PRACTICES IN CHILDREN AGED 1 - 3 YEARS}

\author{
Ratna Indriati, Endang Dwi Ningsih
}

\begin{abstract}
Background : characteristics of a typical toddler, namely the child cannot stay still and move continuously and the lack of control impulses contribute to the incidence of accidental injury in the toddler age. Parents are the party most responsible for the accidents/injuries suffered by toddlers. Injury prevention practices carried out by parents will reduce the incidence of injury to children. Knowledge and attitudes are factors that can influence the formation of mother's behavior in efforts to prevent injuries to children

The aim of the study: this is to determine the relationship between knowledge and attitudes of mothers with injury prevention practices in children aged $1-3$ years. The benefit of the research is to provide an overview of the importance of fostering positive attitudes in mothers so that optimal prevention practices in children are formed

Subject and method : 40 mothers who have children aged 1 - 3 years in Daleman Jetis. This research is in the form of analytic observation, correlation design with cross sectional method. Sampling was saturated sampling. The data obtained were analyzed using the Chi Square test with p: 0.05
\end{abstract}


Results : it shows respondents with high knowledge 29 mothers (72.5\%) moderate knowledge 11 mothers (27.5\%), positive attitudes 36 mothers (90\%) negative attitudes 4 mothers (10\%). Optimal prevention practices were 31 mothers (77.5\%) less than 9 mothers (22.5\%). The results of the analysis of the relationship between maternal knowledge and injury prevention practices obtained $p=0.211(p>0.05)$ which means that $\mathrm{Ha}$ is rejected, the relationship between maternal attitudes and injury prevention practices is obtained $p=0.008(p<0.05)$ which means that Ha is accepted and OR $=15.00$.

Conclusion : knowledge has no relationship with injury prevention practices and attitudes have a significant relationship with injury prevention practices.

Keywords : attitudes, injury prevention practices, knowledge

Korespondensi: Ratna Indriati. Program Studi D3 Keperawatan STIKES PANTI KOSALA. JI. Raya Solo-Baki KM. 4 Gedangan, Solo Baru, Sukoharjo, Jawa Tengah. Email: ratna24173@gmail.com.

\section{LATAR BELAKANG}

Anticipatory guidance merupakan bimbingan yang diberikan kepada orang tua mengenai tahapan perkembangan dari anak sehingga orang tua sadar akan apa yang terjadi pada perkembangan anak dan dapat memenuhi kebutuhan anak sesuai dengan usianya secara optimal. Dalam masa pertumbuhan dan perkembangan anak, semakin meningkatnya mobilitas anak dan meningkatnya perkembangan anak maka membutuhkan disiplin, dan kebutuhan untuk memenuhi keamanan anak (Senja, et al, 2020).

Menurut Riskesdas tahun 2018, prevalensi cedera di Indonesia pada anak usia $1-4$ tahun adalah $8,2 \%$ (Kemenkes RI, 2019) dengan berbagai kemungkinan penyebab diantaranya cedera di rumah dan lingkungannya. Peningkatan kejadian cedera pada anak usia toddler (1 - 3 tahun) terkait erat dengan pengetahuan orang tua dalam memenuhi keamanan anaknya.

Pengetahuan sendiri adalah hasil "tahu" dan ini terjadi setelah orang mengadakan penginderaan terhadap suatu objek tertentu (Wawan dan Dewi, 2011). Tahu juga diartikan sebagai mengingat suatu materi yang telah dipelajari sebelumnya (Tumurang, 2018).
L

Pengetahuan seseorang mengenai suatu obyek akan mendasari terbentuknya perilaku. Orangtua yang memiliki pengetahuan yang benar tentang cedera dan upaya mencegah cedera pada anak akan memungkinkan terbentuknya perilaku pencegahan cedera pada anak. Sebagaimana hasil penelitian yang dilakukan oleh Hastuti (2017) yang berjudul hubungan pengetahuan tentang antisipasi cedera dengan praktik pencegahan cedera pada anak usia toddler di RW 01 Kelurahan Manggalang wilayah Puskesmas Jelekong Kabupaten Bandung. Hasil penelitian menunjukkan sebagian ibu berpengetahuan cukup tentang antisipasi cedera $(44,3 \%)$. Hasil uji Chi-Square diperoleh adanya hubungan antara pengetahuan ibu tentang antisipasi cedera dengan praktik pencegahan cedera pada anak usia toddler ( $p$ value $=0,000$ ).

Selain pengetahuan, terbentuk nya perilaku seseorang bisa dimulai dari perubahan sikap (attitude). Sikap terdiri dari komponen kognitif, perilaku, dan emosi (Wawan dan Dewi, 2011).

Sikap seseorang dicerminkan dalam bentuk perilaku. Perilaku adalah respon individu terhadap suatu stimulus atau suatu tindakan yang dapat diamati dan mempunyai 
frekuensi spesifik, durasi dan tujuan baik disadari maupun tidak. Perilaku merupakan kumpulan berbagai faktor yang saling berinteraksi (Wawan dan Dewi, 2011).

Perilaku merupakan tindakan nyata dari seseorang sebagai respon terhadap stimulus, setelah seseorang memiliki pengetahuan dan sikap. Hal ini ditunjukkan dari hasil penelitian yang dilakukan oleh Dewi dan Indarwati (2011) di Kelurahan Blumbang Kecamatan Tawangmangu Kabupaten Karanganyar didapatkan hasil analisa univariat menunjukkan bahwa sebagian besar responden berpengetahuan rendah (52,9\%), dengan sebagian besar memiliki sikap positif $(60,3 \%)$, dan sebagian besar memiliki praktik baik $(73,5 \%)$. Hasil analisa bivariat didapatkan hubungan antara pengetahuan dengan praktik pencegahan cedera dengan $\mathrm{OR}=4,455$ dan $\mathrm{Cl} 95 \%$ $(1,284-15,449)$ dan terdapat hubungan antara sikap dengan praktik pencegahan cedera dengan $\mathrm{OR}=9.962$ dan $\mathrm{Cl}$ 95\% (2.77435.768). Analisa multivariat menunjukkan bahwa variabel sikap lebih berpengaruh terhadap praktik pencegahan cedera, dibanding dengan variabel pengetahuan.

Penelitian lain yang dilakukan oleh Jamil dan Laksono (2020) didapatkan hasil uji statistik variabel pengetahuan berhubungan dengan praktik pencegahan cedera dengan nilai $p=0,001$ dan $r=0,447$; demikian juga variabel sikap berhubungan dengan praktik pencegahan cedera nilai $p=0,000$ dan $r=0,650$. Kesimpulan penelitian ini adalah pencegahan cedera pada anak pra sekolah membutuhkan pengetahuan dan sikap orang tua yang baik untuk meningkatkan praktik orang tua dalam melakukan pencegahan pada anak pra sekolah. Praktik pencegahan cedera yang dilakukan orang tua akan menurunkan kejadian cedera/kecelakaan pada anak. Menurut Yuliastati dan Arnis (2016) kecelakaan merupakan peristiwa yang sering dialami oleh anak yang dapat melukai bahkan menyebabkan kematian. Orang tua bertanggung jawab terhadap kebutuhan dan keselamatan anak, sehingga orangtua harus memahami karakteristik dan perilaku anak serta menyadari risiko bahaya yang dapat menimbulkan kecelakaan. Untuk itu sangat penting melakukan upaya supaya anak terhindar dari cedera khususnya pada anak usia $1-3$ tahun dimana anak baru menyesuaikan tahap perkembangan motorik kasar yaitu berjalan, berlari, melompat serta anak usia 1-3 tahun mulai memiliki keinginan untuk mencoba hal-hal baru sehingga membutuhkan pengawasan dan peran orangtua untuk menghindarkan cedera pada anak di rumah dan lingkungannya.

Dusun Daleman, Desa Jetis merupakan dusun dengan jumlah anak usia toddler cukup banyak yaitu 40 anak. Dengan melihat karakter anak usia 1-3 tahun yang rentan untuk mengalami kecelakaan dibandingkan anak yang lebih besar dan melihat dari hasil penelitian terdahulu yang menunjukkan adanya hubungan pengetahuan dan sikap dengan praktik pencegahan kecelakaan pada anak serta di Dusun Daleman Desa Jetis selama ini belum pernah dilakukan penelitian mengenai pencegahan cedera pada anak maka peneliti tertarik untuk melakukan penelitian dengan judul "Hubungan Pengetahuan dan sikap lbu tentang Antisipasi Cedera dengan Praktik Pencegahan Cedera pada Anak Usia Toddler".

Penelitian ini merupakan replikasi dari penelitian terdahulu. Adapun perbedaan yang ditemukan pada penelitian ini dari penelitian sebelumnya yaitu responden untuk 
penelitian ini adalah orang tua dari anak usia toddler sedangkan pada penelitian sebelumnya orang tua dari anak usia pra sekolah. Perbedaan lain dari penelitian sebelumnya adalah lokasi penelitian dimana lokasi penelitian yang berbeda memungkinkan karakteristik responden yang berbeda pula.

\section{TUJUAN PENELITIAN}

Untuk mengetahui apakah ada hubungan antara tingkat pengetahuan dan sikap lbu tentang antisipasi cedera dengan praktik pencegahan cedera pada anak.

\section{METODE}

Penelitian ini merupakan penelitian analitik observasional dengan desain korelasi. Lokasi penelitian di dusun Daleman desa Jetis Sukoharjo. Pengumpulan data dengan menggunakan kuesioner dan data yang sudah terkumpul dianalisa menggunakan $\mathrm{Uji} C h i$ Square dengan program SPSS seri 18.0.

\section{SUBJEK}

Subyek penelitian adalah Ibu dari anak usia 1-3 tahun di dusun Daleman desa Jetis, pengambilan sampel menggunakan teknik sampling jenuh dengan jumlah sampel 40 responden. Variabel penelitian meliputi pengetahuan ibu dan sikap ibu tentang antisipasi cedera sebagai variabel bebas dan praktik pencegahan cedera pada anak usia toddler sebagai variabel terikat.

\section{HASIL PENELITIAN}

Berdasarkan penelitian yang telah dilakukan didapatkan karakteristik responden berdasarkan umur, Pendidikan dan pekerjaan responden beserta hasil penelitian mengenai hubungan pengetahuan dan sikap dengan praktik pencegahan cedera pada anak usia 1-3 tahun, yaitu sebagai berikut :

Tabel 1.

Distribusi Frekuensi

Karakteristik Responden

\begin{tabular}{lcc}
\hline \multicolumn{1}{c}{ Variabel } & $\mathrm{f}$ & $\%$ \\
\hline Umur Ibu & & \\
$20-30$ tahun & 18 & 45 \\
$31-40$ tahun & 20 & 50 \\
$>40$ tahun & 2 & 5 \\
Pendidikan Ibu & & \\
SMP & 1 & 2,5 \\
SMA/SMK & 31 & 77,5 \\
D3 - S1 & 8 & 20 \\
Pekerjaan Ibu & & \\
PNS & 3 & 7,5 \\
Swasta/Wiraswasta & 21 & 52,5 \\
Buruh & 4 & 10 \\
Tidak bekerja (IRT) & 12 & 30 \\
\hline
\end{tabular}

Dari Tabel 1 diketahui bahwa sebagian besar ibu berada pada usia 31-40 tahun yaitu 20 ibu (50\%), pendidikan ibu paling banyak adalah SMA/SMK yaitu 31 orang $(77,5 \%)$, dan pekerjaan ibu sebagian besar adalah swasta/wiraswasta yaitu 21 orang $(52,5 \%)$.

Tabel 2.

Distribusi Frekuensi Pengetahuan, Sikap dan Praktik Pencegahan Cedera

\begin{tabular}{lcc}
\hline \multicolumn{1}{c}{ Variabel } & $\mathrm{f}$ & $\%$ \\
\hline Pengetahuan & & \\
Tinggi & 29 & 72,5 \\
Sedang & 11 & 27,5 \\
Sikap & & \\
Positif & 36 & 90 \\
Negatif & 4 & 10 \\
Praktik Pencegahan & & \\
Cedera & & \\
Optimal & 31 & 77,5 \\
Kurang Optimal & 9 & 22,5 \\
\hline
\end{tabular}

Dari data di atas diperoleh informasi bahwa ibu dengan tingkat pengetahuan tinggi sejumlah 29 ibu $(72,5 \%)$ lebih banyak dibandingkan dengan ibu yang tingkat pengetahuannya sedang yaitu 11 ibu $(27,5 \%)$, sebagian besar ibu memiliki sikap positif terhadap antisipasi cedera pada anak yaitu 
36 ibu (90\%) dan 4 ibu (10\%) memiliki sikap negatif. Ibu yang memiliki praktik pencegahan cedera optimal sebanyak 31 anak $(77,5 \%)$ lebih banyak dibandingkan dengan ibu yang kurang optimal dalam praktik pencegahan cedera pada anak yaitu sebanyak $9(22,5 \%)$.

Tabel 3.

Tabulasi Silang Pengetahuan dan Sikap Dengan Praktik Pencegahan Cedera

\begin{tabular}{|c|c|c|c|c|}
\hline \multirow[b]{2}{*}{ Variabel Penelitian } & \multicolumn{2}{|c|}{ Praktik } & \multirow[b]{2}{*}{ Total } & \multirow[b]{2}{*}{$\mathrm{p}$} \\
\hline & $\begin{array}{c}\text { Optimal } \\
(\%)\end{array}$ & $\begin{array}{c}\text { Kurang Optimal } \\
(\%)\end{array}$ & & \\
\hline \multicolumn{5}{|l|}{ Pengetahuan } \\
\hline Tinggi & $\begin{array}{c}21 \\
(72,4)\end{array}$ & $\begin{array}{c}8 \\
(27,6)\end{array}$ & $\begin{array}{c}29 \\
(100)\end{array}$ & 0,211 \\
\hline Sedang & $\begin{array}{c}10 \\
(90,9)\end{array}$ & $\begin{array}{c}1 \\
(9,1)\end{array}$ & $\begin{array}{c}11 \\
(100)\end{array}$ & \\
\hline \multicolumn{5}{|l|}{ Sikap } \\
\hline Positif & $\begin{array}{c}30 \\
(83,3)\end{array}$ & $\begin{array}{c}6 \\
(16,7)\end{array}$ & $\begin{array}{c}36 \\
(100)\end{array}$ & 0,008 \\
\hline Negatif & $\begin{array}{c}1 \\
(25)\end{array}$ & $\begin{array}{c}3 \\
(75) \\
\end{array}$ & $\begin{array}{c}4 \\
(100)\end{array}$ & \\
\hline
\end{tabular}

Dari hasil uji Chi Square dengan tingkat signifikasi $\alpha=0,05$ pada variabel pengetahuan dengan praktik pencegahan cedera diperoleh nilai p sebesar 0,211. Karena nilai $p>0,05$ hipotesis ditolak yang berarti tidak ada hubungan antara pengetahuan dengan praktik pencegahan cedera pada anak. Dan pada variabel sikap dengan praktik pencegahan cedera nilai $p$ sebesar 0,008 . Karena nilai $p<$ 0,05 hipotesis diterima yang berarti ada hubungan antara sikap ibu dengan praktik pencegahan cedera pada anak dan OR: 15,00 yang menunjukkan ibu dengan sikap positif cenderung melakukan praktik pencegahan cedera pada anak sebesar 15 kali.

\section{PEMBAHASAN}

Fase usia toddler merupakan fase usia 1-3 tahun dimana pada usia ini aktivitas yang mendominasi adalah berjalan, berlari, memanjat, meraih/mengambil sesuatu dan berbicara (Suparmi, et al., 2018). Pada usia ini biasanya rasa keingintahuan anak juga tinggi. Dengan karakteristik anak usia toddler yang khas yaitu anak tidak bisa diam dan bergerak terus serta kurangnya impuls kontrol berkontribusi pada insiden cedera yang tidak disengaja dalam usia toddler (Kyle \& Carman, 2015).

Menurut Yuliastati dan Arnis (2016), kecelakaan merupakan peristiwa yang sering dialami oleh anak yang dapat melukai bahkan menyebabkan kematian, seperti luka bakar, jatuh, tertabrak motor/mobil dan tenggelam. Orang tua turut bertanggung jawab terhadap kejadian kecelakaan/cedera yang dialami oleh anak usia toddler. Orang tua terutama ibu perlu melakukan upaya untuk mencegah terjadinya kecelakaan/ cedera pada anak. Dalam penelitian ini, praktik pencegahan cedera pada anak usia 1-3 tahun yang dilakukan oleh ibu di dusun Daleman desa Jetis merupakan tindakan nyata yang sudah terbentuk dimana berdasarkan data pada tabel 2 menunjukkan bahwa jumlah ibu yang melakukan praktik pencegahan cedera yang optimal lebih besar yaitu 31 ibu $(77,5 \%)$, dan masih ada 9 ibu (22,5\%) yang kurang optimal dalam melakukan 
praktik pencegahan cedera pada anak. Dalam penelitian ini memaparkan faktor pengetahuan dan sikap terkait dengan praktik pencegahan cedera yang dilakukan oleh ibu di dusun Daleman.

Berdasarkan Tabel 2 menunjukkan bahwa sebagian besar responden $(72,5 \%)$ memiliki pengetahuan yang tinggi tentang antisipasi cedera pada anak. Salah satu faktor yang mempengaruhi pengetahuan seseorang adalah faktor pendidikan (Wawan dan Dewi, 2011). Melihat dari karakteristik responden pada Tabel 1 menunjukkan hampir seluruh ibu (31 ibu) berpendidikan minimal SMA bahkan ada 8 ibu dengan pendidikan di atas SMA (D3 dan S1). Menurut Wawan dan Dewi (2011), dengan pendidikan yang tinggi maka orang tersebut akan semakin luas pula pengetahuannya, kondisi ini semakin diperkuat dengan era teknologi informasi yang semakin meningkat dimana akses untuk memperoleh berbagai informasi terbuka luas sehingga setiap orang bisa dengan mudah memperoleh informasi sesuai dengan pengetahuan yang dibutuhkan. Demikian pula pada responden dalam penelitian ini dengan pendidikan yang tinggi dan kemudahan dalam memperoleh informasi memungkinkan ibu memiliki pengetahuan yang tinggi tentang perawatan anak khususnya mengenai antisipasi pencegahan cedera pada anak.

Berdasarkan data pada Tabel 3 , ibu dengan pengetahuan yang tinggi sebagian besar $(72,4 \%)$ melakukan praktik pencegahan cedera dengan optimal dan hanya $27,6 \%$ yang melakukan praktik pencegahan kurang optimal. Akan tetapi pada ibu yang pengetahuannya dalam kategori sedang juga sebagian besar $(90,9 \%) \quad$ melakukan praktik pencegahan cedera secara optimal.
Dari data tersebut menunjukkan baik pada ibu yang berpengetahuan tinggi maupun sedang telah melakukan praktik pencegahan cedera secara optimal. Dan dari hasil analisa statistik hubungan pengetahuan ibu dengan praktik pencegahan cedera pada anak usia toddler di dusun Daleman diperoleh $p$ value : 0,211 ( $p>0,05)$ yang berarti tidak ada hubungan antara pengetahuan ibu dengan praktik pencegahan cedera pada anak.

Hasil penelitian ini berbeda dengan penelitian yang dilakukan oleh Putri (2019) tentang hubungan antara tingkat pengetahuan orang tua dengan perilaku pencegahan cedera pada anak balita. Dari hasil analisa statistik bivariat menggunakan uji Chi Square diperoleh $p$ value : 0,016 , hal ini menunjukkan ada hubungan antara tingkat pengetahuan dengan praktik pencegahan cedera pada anak usia balita di Desa Bangunjiwo Kasihan Bantul Yogyakarta. Demikian pula penelitian yang dilakukan oleh Hastuti (2017) yang menunjukkan terdapat hubungan yang signifikan antara pengetahuan ibu tentang antisipasi cedera dengan praktik pencegahan cedera pada anak usia toddler ( $p$ value: 0,000). Dalam penelitian ini pengetahuan ibu tentang antisipasi cedera tidak mempengaruhi praktik pencegahan cedera pada anak usia toddler di dusun Daleman, seperti yang dipaparkan oleh Induniasih dan Ratna (2017) dimana perilaku tidak selalu didasari dengan pengetahuan, masih terdapat beberapa faktor lain yang mempermudah pembentukan perilaku seseorang yaitu kepercayaan, keyakinan, nilai, norma sosial, budaya dan faktor sosio demografi lainnya dimana faktor-faktor tersebut dimungkinkan bisa mempengaruhi praktik pencegahan cedera yang dilakukan oleh responden dalam penelitian ini. 
Berdasarkan data pada Tabel 2 tentang sikap responden terhadap antisipasi cedera pada anak menunjukkan sebagian besar responden memiliki sikap positif yaitu sebesar 36 ibu (90\%) dan hanya 4 ibu (10\%) yang memiliki sikap negatif terhadap antisipasi cedera. Dari tabel 3 menunjukkan Ibu yang memiliki sikap positif sebagian besar $(83,3 \%)$ melakukan praktik pencegahan cedera pada anak secara optimal dan ibu yang memiliki sikap negatif sebagian besar (75\%) melakukan praktik pencegahan cedera pada anak secara kurang optimal. Dari hasil uji Chi Square dengan tingkat signifikasi $\alpha=0,05$ diperoleh nilai $p$ sebesar 0,008 . Karena nilai $p<$ 0,05 hipotesis diterima yang berarti ada hubungan antara sikap ibu terhadap antisipasi cedera dengan praktik pencegahan cedera pada anak usia 1-3 tahun di dukuh Daleman Desa Jetis. OR :15,00 yang menunjukkan ibu dengan sikap positif terhadap antisipasi cedera berpeluang melakukan praktik pencegahan cedera pada anak sebesar 15,00 kali lebih besar dibandingkan ibu yang bersikap negatif.

Sikap menurut Purwanto yang dikutip oleh Wawan dan Dewi (2011) merupakan pandangan atau perasaan yang disertai kecenderungan untuk bertindak sesuai pandangan dan perasaannya. Sikap positif kecenderungan tindakan adalah mendekati, menyenangi dan mengharapkan obyek tertentu. Sikap mempunyai segi-segi motivasi, sehingga seseorang yang mempunyai sikap positif akan mendukung obyek sikap. Sikap positif yang dimiliki oleh responden dalam penelitian ini ditunjukkan dari seluruh ibu memandang bahwa pencegahan cedera pada anak penting untuk dilakukan dan seluruh ibu juga menyatakan bersedia dan berusaha untuk melakukan pencegahan cedera pada anak. Dengan sikap positif terhadap antisipasi cedera pada anak yang dimiliki responden maka responden cenderung mendukung tindakan antisipasi cedera yang ditunjukkan dari sebagian besar responden $(82,5 \%)$ berupaya untuk mencari informasi yang benar mengenai pencegahan cedera pada anak. Dengan sikap positif tersebut telah mendorong ibu untuk melakukan upaya-upaya dalam mencegah cedera pada anak, dimana sebagian besar ibu $(77,5 \%)$ melakukan praktik pencegahan cedera secara optimal dengan menjaga keamanan lingkungan rumah sehingga menghindarkan anak dari kecelakaan, melakukan pengawasan dan memberikan perhatian pada aktivitas anak usia toddler.

Hasil penelitian ini mendukung penelitian yang dilakukan oleh Jamil dan Laksono (2020) yang menunjukkan terdapat hubungan yang signifikan serta kekuatan hubungan yang cukup dan kuat antara sikap orang tua dengan praktik pencegahan cedera pada anak pra sekolah ( $p$ value : 0,000 dan $r$ : 0,650). Demikian pula penelitian yang dilakukan oleh Dewi dan Indarwati (2011) yang menunjukkan terdapat hubungan yang signifikan antara sikap orang tua dengan praktik pencegahan cedera pada anak usia toddler ( $\mathrm{p}$ value : 0,000) dengan OR : 9,962 artinya orang tua yang memiliki sikap positif berpeluang untuk melakukan pencegahan cedera pada anak usia toddler sebanyak 9,962 kali lebih besar dibandingkan dengan orang tua yang bersikap negatif. Demikian pula dalam penelitian ini sikap yang positif mempengaruhi praktik pencegahan cedera yang dilakukan oleh ibu terhadap anak. 
Terdapat beberapa faktor yang dapat mempengaruhi sikap positif seseorang, diantaranya pengalaman personal yang langsung dialami akan memberikan pengaruh yang kuat, adanya sumber pesan dimana semakin percaya dengan orang yang mengirimkan pesan maka seseorang akan semakin menyukai untuk dipengaruhi oleh pemberi pesan dan media massa yang hadir di tengah-tengah masyarakat bisa membangun sikap masyarakat (Wawan dan Dewi, 2011). Dengan hasil penelitian ini dimana sikap ibu berpengaruh pada pembentukan perilaku pencegahan cedera pada anak maka perlu dibangun sikap positif pada orang tua dengan mengoptimalkan faktor-faktor yang mempengaruhi pembentukan sikap, sehingga dengan orang tua melakukan praktik pencegahan cedera yang optimal maka keamanan anak usia toddler dapat dipertahankan dan anak terbebas dari cedera.

\section{KESIMPULAN}

Berdasarkan hasil penelitian diperoleh kesimpulan bahwa pengetahuan ibu tidak memiliki hubungan dengan praktik pencegahan cedera pada anak usia toddler $(p=0,211)$ dan sikap ibu memiliki hubungan dengan praktik pencegahan cedera pada anak usia toddler $\quad(p=0,008) \quad$ dengan $\mathrm{OR}=15,00$ yang menunjukkan ibu dengan sikap positif terhadap antisipasi cedera berpeluang melakukan praktik pencegahan cedera pada anak sebesar 15,00 kali lebih besar dibandingkan ibu yang bersikap negatif.

\section{SARAN}

Petugas Kesehatan diharapkan lebih meningkatkan perannya sebagai edukator bagi masyarakat khususnya dalam memberikan pendidikan mengenai antisipasi cedera pada anak. Dengan informasi yang diberikan oleh petugas Kesehatan maka akan mempengaruhi terbentuknya sikap positif orang tua terhadap antisipasi cedera pada anak dan Orang tua diharapkan meningkatkan sikap positif terhadap antisipasi cedera pada anak sehingga mendukung terbentuknya praktik pencegahan cedera yang dilakukan oleh orang tua terhadap anak

\section{DAFTAR PUSTAKA}

Dewi dan Indarwati. 2011. "Hubungan Antara

Pengetahuan dan Sikap Orangtua tentang Bahaya Cedera dan Cara Pencegahannya dengan Praktik Pencegahan Cedera pada Anak Usia Toddler di Kelurahan Blumbang Kecamatan Tawangmangu Kabupaten Karanganyar". Jurnal Kesehatan STIKES Aisyiyah Surakarta. 8(2). Diakses pada tanggal 28 Oktober 2020.

Hastuti, D. 2017. "Hubungan Pengetahuan tentang Antisipasi Cedera dengan Praktik Pencegahan Cedera pada Anak Usia Toddler di RW $01 \quad$ Kelurahan Manggahang Wilayah Puskesmas Jelekong Kabupaten Bandung". Jurnal Keperawatan Komprehensif. 3(1). Diakses pada tanggal 28 Oktober 2020.

Induniasih dan W. Ratna. 2017. Promosi Kesehatan Pendidikan Kesehatan dalam Keperawatan. Pustaka Baru Press, Yogyakarta.

Jamil, M. dan B.B. Laksono 2020. "Hubungan Pengetahuan dan Sikap Orang Tua dengan Praktik Pencegahan Cedera Pada Anak Pra Sekolah". Jurnal Surya. 8(1). Diakses pada tanggal 28 Oktober 2020. 
Kemenkes RI. 2019. Laporan Provinsi Jawa Tengah RISKESDAS 2018. Badan Penelitian dan Pemberdayaan Kesehatan, Jakarta.

Kyle, T. dan. S. Carman. 2015. Buku Ajar Keperawatan Pediatri. Ed II, Vol. 1. Alih Bahasa Devi Yuliana. Buku Kedokteran EGC, Jakarta.

Putri, I.M. 2019. "Hubungan Tingkat Pengetahuan Orang Tua dengan Perilaku Pencegahan Cedera pada Anak Balita". Midwifery Journal Kebidanan. 4(1). FIK UM Mataram. Diakses tanggal 11 April 2021.

Senja, et al. 2020. Keperawatan Pediatri. Bumi Medika, Jakarta.

Suparmi, et al. 2018. Buku Saku Bayi dan Balita Sehat. CV Trans Info Media, Jakarta Timur.

Tumurang, Marjes N. 2018. Promosi Kesehatan. Indomedia Pustaka, Sidoarjo.

Wawan dan Dewi. 2011. Teori dan Pengukuran Pengetahuan, Sikap, dan Perilaku Manusia. Nuha Medika, Yogyakarta.

Yuliastati dan A. Arnis. 2016. Keperawatan Anak. Kementerian Kesehatan Republik Indonesia, Jakarta Selatan. 